\title{
Review
}

Author(s): E. A. B.

Review by: E. A. B.

Source: The Geographical Journal, Vol. 60, No. 3 (Sep., 1922), pp. 228-229

Published by: geographicalj

Stable URL: http://www.jstor.org/stable/1781067

Accessed: 26-06-2016 13:00 UTC

Your use of the JSTOR archive indicates your acceptance of the Terms \& Conditions of Use, available at

http://about.jstor.org/terms

JSTOR is a not-for-profit service that helps scholars, researchers, and students discover, use, and build upon a wide range of content in a trusted digital archive. We use information technology and tools to increase productivity and facilitate new forms of scholarship. For more information about JSTOR, please contact support@jstor.org.

The Royal Geographical Society (with the Institute of British Geographers), Wiley are collaborating with JSTOR to digitize, preserve and extend access to The Geographical Journal 


\section{AUSTRALIA AND PACIFIC REGIONS}

In the Tracks of the Trades. - Lewis R. Freeman. London: William Heinemann. 1921. Pp. 380. Illustrations from photographs. 25s. net.

This is an account of a yachting cruise in the Pacific, undertaken in 1908 ; and it has some points in common with many other yachting narratives, which, however exhilarating to those engaged in the cruise, are usually trivial and lacking in serious interest. In this instance the yacht and her owner's party were American, and the book, though published in London, was "printed in the U.S.A." ; therefore we will not quarrel with the writer's grammar and composition, nor with certain words he affects in a manner strange to English ears - such as "funicular" as applied to a volcanic cone, "mavericks," "sliver," and "ululating." What one is loth to excuse, however, is the author's habit of relating his impressions in forced pseudo-jocular language which, if it pleased his own fancy in the writing, serves in print only to irritate the sober-minded reader and exhaust his patience. An obvious feature in this is a lot of absurd exaggeration, inseparable perhaps from the style; but the book teems besides with downright errors, and no care has been taken to spell native words or names correctly, whether of persons or places, nor to differentiate between the Polynesian terms curent in the several groups of islands visited.

Fellows of our Society will be surprised to learn from Mr. Freeman (p. I5 I) that "The Society Islands took their name from the Royal Geographical Society, which sent an expedition there in 1868 to observe the transit of Venus"! This is only one example of sheer carelessness. But a more serious sin has been committed in publishing reproductions from non-original photographs as the author's own ; and in the chapters on Fiji several of these, representing natives of the Solomon Islands and one of their canoes, are shown as "Fijians," and as "A Fijian head-hunting canoe"-though every one knows that head-hunting was never practised in Fiji (pp. 298, 299, 362). B. G. C.

\section{GENERAL}

A Short History of British Expansion.- James A. Williamson. London : Macmillan \& Co. I922. Pp. xxvi. and 648. Maps. 25s. net.

Dr. Williamson's 'Short History of British Expansion' is a substantial and comprehensive book. He begins with feudal England and mediæval trading corporations, and ends with Imperial Congresses and the Montagu-Chelmsford Report, and between these far-separated matters he marshals into a connected story all the diverse incidents and experiences, the growth and fluctuations of policy, the wars and the peaces which have gone to the making, the collapse, and the remaking of the British Empire. Such a book was much to be desired, for though much has in recent years been written about one or another period of British colonial history, no historian has attempted to combine the result of recent researches and give us the whole story in the light of our present knowledge and point of view. The student has every reason to be grateful to Dr. Williamson for taking in hand a task at once so difficult and so promising.

One of the great problems in writing the history of such a state as the British Empire is to know whether one should stand at the centre, as it were, or at successive points on the circumference. Dr. Williamson solves this by attempting each in turn. The subject, he tells us in his preface, "entails working sometimes from the centre, to obtain a proportioned view and to deal with ideas of policy, and sometimes in compartinents to trace the history of various undertakings." We cannot comment in any detail on so extensive a 
history, but we may say in general that Dr. Williamson seems to us more successful when he is working from the centre, and when he describes the earlier centuries of British expansion, the explorations, and the foundation of the Mercantile Empire - the old colonial system, than he is when he deals with the nineteenth century and the history of the present Dominions. On the earlier part he writes with fuller knowledge and has given himself far more scope; three-quarters of his volume is occupied with this, while to the wonderful story of the refoundation and growth of the British Empire since I 783 he has given only a quarter of his space, and this part of the book becomes little more than a concise summary of events in which the manifold and amazing interest and significance of the story is lost.

The book is illustrated by a number of instructive and original maps (though here again the history of the nineteenth century is strangely neglected), and after each section a bibliography of secondary works-useful, because brief and critical-has been added.

E. A. B.

\section{THE MONTHLY RECORD}

\section{EUROPE}

\section{The Ordnance Survey: Retirement of Sir Charles Close.}

Colonel Sir Charles Close, K.B.E., F.R.S., who retired in August from the Ordnance Survey on reaching the age limit, will take with him on his retirement the good wishes of all British geographers. Since he was appointed Director-General in 19I I the Ordnance Survey has developed a scientific activity which not even the long interruption of the War and the stringent retrenchments of Peace were able to extinguish. Under his distinguished direction the stations of the principal triangulation have been in large part restored, and the true weight of the triangulation established by the operations round the new Lossiemouth base. A new precise levelling, with fundamental benchmarks referred to three self-recording tide-gauges, has been brought nearly to the point of publication. A new technical series of publications-the Professional Papers of the Ordnance Survey-has been established. An Archæology Officer and a Mathematical Adviser have been added to the staff of the Survey. And in the offices at Southampton is now installed the Central Bureau of the Carte du Monde au Millionième.

With all this scientific activity there has been great progress in the supply of maps for public needs, and great improvement in the methods of sale. The engraved quarter-inch (recently published as an Atlas with Index), the new Popular Edition of the one-inch, and the combined sheets of Holiday Districts in most attractive covers, are but examples of the general advance which has been made in all the series. The increase in cost of production due to the war has forbidden for the time being any further progress with a delicately beautiful one-inch map that has been seen in proof : a triumph of colour printing. The work of the Ordnance Survey during the War, when it was largely diverted from its normal functions and extended overseas, was of fundamental importance to the success of the British arms, but a most unwelcome interruption to the programme which Sir Charles Close had in mind when he was made Director-General. $\mathrm{He}$ is to be congratulated on his remarkable success in the most difficult circumstances.

Sir Charles Close is succeeded at Southampton by Colonel E. M. Jack, 